Article

\title{
The Santa Barbara Oil Spill and Its Effect on United States Environmental Policy
}

\author{
Teresa Sabol Spezio \\ Environmental Analysis Program, Pitzer College, Claremont, CA 91711, USA; teresa_spezio@pitzer.edu
}

Received: 5 July 2018; Accepted: 28 July 2018; Published: 3 August 2018

check for updates

\begin{abstract}
The National Environmental Policy Act of 1970 (NEPA) paved the way for comprehensive federal environmental policy in the United States. NEPA has successfully allowed citizens and others to become active participants in the environmental decision-making process for federal infrastructure projects throughout the evolution of environmental policy in the United States. Its efficacy was enhanced because of an oil spill off the Santa Barbara coast in January 1969. This disaster gave the framers of NEPA an example of the consequences of the lack of environmental policy in federal decision making. Using their original proactive approach along with the reactive response to the spill, they created a policy that has can be seen as a foundation for 21st century sustainability and resilience programs.
\end{abstract}

Keywords: Santa Barbara oil spill; National Environmental Policy Act; environmental policy; environmental decision making

\section{Introduction}

As humans, corporations, and governments consider how to incorporate sustainability and resilience into decision making, it is important to look back at the process that created comprehensive federal environment policy in the United States and its connections to sustainable policies in the 21st century. This analysis is also important as the Trump Administration attempts to reduce environmental regulatory review for infrastructure projects including the border wall and oil and gas drilling in the Arctic National Wildlife Refuge (ANWR) and in the Outer Continental Shelf (OCS). Approximately fifty years ago, on 1 January 1970, President Richard Nixon signed the National Environmental Policy Act (NEPA) into law that set federal environmental policy and created a framework for the environmental reviews that are an integral part of infrastructure projects that are funded by the federal government Nixon and Congress enacted NEPA in response to environmental disasters (specifically the Santa Barbara oil spill of 1969) and the dawning realization that human activities had caused extensive air, water and land pollution in the United States. Senator Henry "Scoop" Jackson and his aides worked to create an integrated approach that considered the interconnections between human activities and environment. In addition, NEPA provided citizens with regulatory methods to become involved in the planning process for federal infrastructure projects. Finally, NEPA provided the federal government with a mission statement for comprehensive environmental policy and can be seen as a foundation for sustainability and resilience movements of the 21st century.

NEPA was enacted after twenty-five years of extensive industrial development in response to changes that occurred after World War II. During the post war years, development, population and pollution exponentially increased. The actions caused the American public to begin to consider their effect on the air, water, and land [1,2]. In addition, people had more time to contemplate the effects because the automobiles and appliances increased their leisure time. With the extra time, the middle class looked around and saw pollution belching from coal-fired power plants, steel and aluminum plants and myriad manufacturing facilities into the air and water in their communities. 
They began to push back on the pollution. In 1965, public opinion polls first included questions about pollution. Opinion Research Corporation asked a national sampling of Americans whether they agreed that air and water pollution where they lived was serious or very serious. This poll reported that thirty-five percent and twenty-eight percent agreed with that statement in regards to water pollution and air pollution, respectively. By 1970 - the year that NEPA was signed-the numbers increased to seventy-four and sixty-nine percent, respectively [3]. The 1970s were a time of increased federal involvement in pollution issues. When Nixon signed NEPA, he hoped that the "decade of the seventies will be known as the time when this country regained a productive harmony between man and nature" [4].

The federal government enacted NEPA in response to flawed environmental decision making by federal agencies. An oil spill from an offshore shore oil platform off the Santa Barbara coast in January 1969 revealed to Congressional representatives that federal agency officials had ignored the environmental concerns of the local citizens, and their lack of engagement caused extensive pollution. The Interior Department's goals for approving the offshore oil platforms included exploiting natural resources (e.g., natural gas and oil) for revenues to help pay for the Vietnam War and social programs. But NEPA's roots were not entirely reactionary. Much like sustainability and resilience programs, its development began with a look to the future. In 1963, Lynton Caldwell, a political scientist asked, can humans consider the environment "to give us insight into relationships between specific social, economic, or political problems-into the interrelationships between the parts and the whole?" [5] (pp. 132-133). From this question, Congressional representatives asked whether decisions being made at the governmental level took into account myriad avenues for protecting not yet polluted land and then worked to create a bill that would answer this query. The reactive and proactive foundation is integral to the effectiveness of NEPA as it enters its second half century. This paper explores how the proactive approach from planners, political scientists, and federal decision makers became entangled with the reactive response to the Santa Barbara oil spill. NEPA's slow evolution combined with its authors' fast reaction after the Santa Barbara spill created a law that has weathered the changes of federal environmental law and policy and created a system for the federal government to consider sustainable actions as federal money builds infrastructure and exploits natural resources.

\section{Santa Barbara Oil Spill-1969}

Since the 1940s, the federal government looked to the oil underneath the Outer Continental Shelf off the coasts of Louisiana, Texas and California as a revenue generator and as a place to produce more domestic oil for the increasing needs of American industry and public. In addition, the oil companies worked to develop methods to explore, drill and produce oil in deeper and deeper waters. In 1965, after years of litigation in the courts and actions in Congress, the Supreme Court held that the tidelands (land underneath the ocean) in the Santa Barbara Channel were "owned" by the federal government from the three-mile mark [6,7]. With this decision, the Johnson Administration had a new revenue generator to assist in funding his social programs and the Vietnam War [8]. With pressure from the Bureau of Budget, Interior Department officials worked to set sale dates for oil leases. In fact, the Interior officials pushed through the sales over the objections of the Santa Barbara community. They would not be aware that an oil well from an offshore platform in federal waters in the Santa Barbara Channel would cause one of the largest spills off the United States coast. In comparison, the largest spill was the Deepwater Horizon spill, in April 2010. The federal government estimated that 210 million gallons of oil spilled into the Gulf of Mexico ([9], p. 120).

With little to no public input from local residents, Union Oil located an offshore platform and began drilling oil wells approximately five miles from Summerland. The drilling began in early January 1969 for a deep well from the platform. The well-3479 feet below the ocean bottom-was successfully completed on 28 January 1969. As the drilling crew worked to remove the casing and set the well; the well blew out. A blowout is caused when the pressure of the drilling mud is less dense and has a lower pressure than the artesian properties of the underground oil and gas. At the platform, 
the workers closed the well by dropping the pipe and closing the hole since the blowout preventer did not operate properly. The workers breathed a sigh of relief. Unfortunately, the system of faults that run under most of California and its tidelands allowed mud and natural gas to escape from the fault lines. Eventually the oil and natural gas began spewing from the fault lines. Without a central location for stopping the oil, Union Oil and its contractors worked to slow the oil from reaching the Santa Barbara coast and beaches. For ten days, the oil spewed from myriad openings while Union Oil with federal government oversight worked to stop the oil. Between 22,000 and 220,000 gallons of oil per day escaped into the channel for ten days ([8], p. xvi).

The response to the spill was unsuccessful in removing, containing or dispersing oil. Due to high winds, strong currents and large waves from incoming winter storms, the oil haphazardly moved in the Santa Barbara Channel. Union Oil tried to use booms to keep the oil from the reaching the beaches, but the conditions caused the booms to break up and sink. By the seventh day, the slick covered approximately eight hundred square miles from Carpinteria to Goleta including the Channel Islands. On shore, residents and workers picked up dead birds and brought countless oil-covered birds to two bird rehabilitation centers for treatment. Few birds survived. In 1969, no surfactant existed to remove the oil from the birds without removing the birds' essential oil. Oil continued to break through barriers and coat the beaches and coast [10]. Workers from oil companies and local colleges, inmates, and others cleaned the coast using straw, high pressure washers, shovels and other hand tools to remove the oil. Studies never determined the impact the oil had on the marine organisms and plants in the channel.

While the oil was spewing from the fault lines and covering the beaches and coast, the Nixon Administration worked to contain and manage the spill with Union Oil. The spill occurred just eight days after Nixon's inauguration. The lack of organization can be attributed to the timing but the organization of the federal government and the lack of a central organization for environmental disasters problematized the Nixon Administration's newness. In the near term, the Nixon Administration failed to manage the debacle created by the Johnson Administration. Nixon's newly approved Interior Secretary Walter Hickel did not effectively communicate with Santa Barbara residents and officials. His indecision about further drilling in the channel compounded the distrust of the federal government by the Santa Barbara residents. To make matters worse, media splashed the effects of the spill on television, newspapers and magazines. Viewers with their new color TVs were shocked to watch the beautiful Santa Barbara beaches turn black. Santa Barbara residents organized to stop the drilling and publicize that the Interior Department had ignored their pollution concerns. Hearings in California and Washington D.C., visits to Santa Barbara by Nixon and Congressional representatives, and the continued flow of oil increased awareness of the spill $[8,10-12]$.

The federal government's disregard of the concerns of the Santa Barbara residents and officials became the impetus for the reactive response to pass comprehensive environmental policy. Since the 1930s, the Santa Barbara residents protested against oil drilling in the Santa Barbara Channel. Oil companies built the first oil derricks on the Summerland coast to exploit the near shore oil reserves in the late 1800s and early 1900s. As technology advances allowed for deeper and deeper drilling in the open ocean, Santa Barbara residents worked to minimize the number of oil platforms in the channel. In the 1940s, the Truman Administration sued the state to take title to the channel tidelands. In 1950s, Eisenhower worked with Congress to pass the Submerged Land Act which gave the coastal states title to the tidelands three miles from the low tidemark. The law allowed the federal government to lease tidelands for oil exploration and production from the three-mile mark [13]. California continued to oppose the federal government. Santa Barbara residents also resisted the presence of the federal government; they wanted more control over the activities in the channel. The spill demonstrated that the citizens and government of California had lost the battle (oil drilling occurred in the Santa Barbara Channel) but the larger war (the fight for environmental protection and comprehensive environmental policy) was won with the passage of NEPA and many other laws including the Clean Water Acts of 1970 and 1972 [8]. 
With the opening of federal tidelands in California in 1966, the Johnson Administration fast tracked the approval process for offshore drilling. Actually, the Johnson Administration was so sure that it would win the Supreme Court case that it planned for channel lease before the Supreme Court decision [10]. The first lease sale occurred in January 1967 less than one year after the Supreme Court decision. The architects of this strategy were Interior Department officials J. Cordell Moore and Eugene Standley. Moore, the Assistant Secretary of Mineral Resources believed that domestic oil production was an important component of the United States' economy. Standley, a staff engineer, was Moore's assistant. During their three and half years in their positions at the Interior Department offshore leasing in the Gulf of Mexico and off California increased exponentially. Although, the lease sale documents acknowledged the concerns of Santa Barbara and California residents and officials, they never took the concerns seriously. Their refusal to listen to and disrespect of the Santa Barbara official and residents caused Congressional representatives to use the pre-spill actions of the Interior Department officials to show the importance of creating a permanent environmental policy.

\section{Environmental Regulatory Evolution}

As mentioned, Nixon decreed the 1970s to be the 'Environment Decade'. His words proved prescient. Between 1970 and 1980, numerous federal environmental protection laws passed Congress and were signed by Presidents Nixon, Ford and Carter including the Clean Air Act, Safe Drinking Water Act, and Comprehensive Environmental Response, Compensation and Liability Act. Political scientists call the first decade of environmental policy creation-an era of command and control. Federal government policy makers believed that they could create and/or facilitate technological fixes to eliminate industrial pollution or find ways to limit pollution into air, water, and land. The laws that passed during the 1970s were highly prescriptive with specific requirements for industry and others to abate pollution in water and air and on land. NEPA passed during this era but NEPA does not fit into the command and control narrative of the first generation of environmental laws [14].

NEPA set up a policy that eventually dictated the actions of federal agencies in regard to the environmental impacts of federal projects. But more importantly it gave the many agencies and organizations inside the federal government the tools and a mandate to consider the effects of large projects on the environment. The author of NEPA, Senator Henry "Scoop" Jackson (D-Washington) was responding to two different problems coming from the lack of federal leadership. One issue involved government agencies refusal to consider the negative environmental aspects of its decisions. Specifically, the Interior Department and its bifurcated mission of exploiting and protecting natural resources was the agency that brought this need to the forefront of Congressional representatives of both parties with its handling of the Santa Barbara offshore oil platforms. The second issue involved the lack of central planning between agencies when considering development of federal lands. For example, three federal agencies—the National Park Service, the Department of Transportation, and the Army Corps of Engineers-had different plans for land near the Everglades National Park without understanding that their plans conflicted. The Park Service wanted to expand the park, the Department of Transportation wanted to build an airport for supersonic transport (SST), and the Army Corps of Engineers wanted to construct a complicated system of dikes and levees to provide water for agricultural expansion. When Jackson corralled each agency head to discuss the differing desires for the land, he unsurprisingly determined that each agency only then became aware of their conflicting plans. In this article, I will concentrate on the first issue.

Prior to 1 January 1970, the federal government did not have a comprehensive policy for considering the environmental effects of projects. In fact, the idea of a comprehensive environmental policy was a fairly new idea. Few people considered the impact of their actions when constructing buildings, buying appliances and most other activities in the middle 20th century. But with the rise of environmental concerns, highlighted by Rachel Carson's Silent Spring, Henry Fairfield Osborn's Our Plundered Planet, and William Vogt's Road To Survival, planners and others began to consider the wider world as humans and their governments developed and polluted land, water and air. One political 
scientist who ultimately became integral to the passage of NEPA wrote about the environment as a public policy issue was Lynton Caldwell. In 1963, Caldwell published his groundbreaking article that proposed "the environment as an integral concept for planning and developing projects [5]."

Political scientists describe the evolution of domestic environmental policy in three specific categories or generations. The generations can be called: (1) 'Command and control', (2) 'cost and efficiency'; and (3) 'it's complicated' [14,15]. The U.S. may now be entering a fourth generation; what can be called the 'denial generation'. The oil spill is part of the first generation. The first generation began in the middle 1960s and continued until the election of Ronald Reagan. During these fifteen years, Congress passed legislation that worked from the idea that if it set deadlines and standards for air and water emissions and developed incentives and penalties (carrots and sticks) for meeting the deadlines and standards, environmental protection goals would be accomplished. For example, the Clean Air Act of 1970 (CAA) set a goal that air quality standards for criteria pollutants would be met within five years. In addition, it set specific standards such as the 8-h standard of 140 micrograms/cubic meter for ozone. The laws were enacted as the United States and its scientists and engineers sent men to the moon and technological optimism was at its zenith. The United States won World War II and were winning the Cold War; therefore, eliminating pollution was attainable. Of course, air pollution standards, along with water pollution standards still have not been met but air and water quality have improved remarkably since the 1960s. Understanding that these laws required a single agency to educate, manage and enforce the laws, the Nixon Administration created the U.S. Environmental Protection Agency (U.S. EPA). With this re-organization, businesses and citizens had a single agency to work with to minimize and reduce pollution. But at the same time, the U.S. EPA became the agency that enforced the environmental protection laws which allowed them to become the target for government reform.

The second generation came to fruition as it became clear that the environmental goals developed in the 1970s were not easily met. The reasons for the failures involved many parties including the regulated community's complaints about costs and the naïve expectations of the policy makers that technology could be easily and cheaply developed to reduce emissions. In addition, punitive, monetary penalties were the primary response to non-compliance. The mandated monetary penalties for the non-compliance caused many of the regulated community to lobby Congress and the more readily agreeable Reagan Administration to change the modus operandi of the environmental regulations. Reagan connected western states' and the regulated community's complaints to shrink federal natural resource and environmental protection programs. With the small government approach, Reagan attempted to change the enforcement and regulation of the laws without changing the original goals and strategies of the laws. He wanted to consider the costs and benefits of the laws to understand the effectiveness. Since Congress and the executive branch did not include risk analysis and cost effectiveness into the original laws, federal court decisions ruled that they could not be included in the regulatory changes. The laws needed to change. The Reagan Administration was unable to convince a majority of Congressional representatives to apply these changes, so they concentrated on non-regulatory mechanisms including market incentives and voluntary initiatives for environmental improvements. Therefore, throughout the Reagan Administration's tenure, he reduced the power and effectiveness of U.S. EPA. For example, in his first budget request Reagan reduced U.S. EPA's budget by $35 \%$. With this reduction, the ability of the states and the U.S. EPA to enforce the regulations was greatly reduced. Although Reagan was unable to make lasting changes to most of the foundational environmental protection laws, his administration persuaded Congress to introduce risk and cost effectiveness into new laws $[14,15]$.

For example, Section 812 of the Clean Air Act (CAA) of 1990 included a requirement to periodically review scientific studies to assess the costs and benefits of the regulations. Embedded in the analysis are risk calculations for preventing myriad air pollution related illnesses including asthma, heart attacks and lower IQ levels for children exposed to lead emissions. U.S. EPA reported to Congress three scientific reviews in October 1997, November 1999 and April 2011. Each report showed that the CAA public health and environmental benefits far exceeded the costs of compliance for industry and others 
to reduce and minimize air pollution emissions [16-18]. The reports aggregated the programs of the CAA and did not specify the costs and benefits of each program of the CAA. Industry lobbyists, small government proponents and others who had hoped that the cost-benefit analyses would show the costs to comply with the CAA would be higher than the benefits attempted to show the limitations of the U.S. EPA methods. The critics wanted each program of the CAA to be reviewed for its costs and benefits. They believed that a few programs such as removing lead from gasoline which provided substantial benefits overshadowed other programs where costs exceeded benefits [19]. The 2011 revision continued to use the aggregate method.

In many ways, the inclusion of costs and benefits has fundamentally changed the way the U.S. EPA has created and enforced regulations. Most importantly, the CAA requirements brought into the conversation the idea of risk and risk analysis for almost every regulation. Bringing risk and its associated uncertainties created a third generation of environmental protection policy. As pollution's effects became more elusive (e.g., climate change, increase in visually undetected pollutants) and did not have the significant visual improvements of the first twenty years of environmental policy, questions from Congressional representatives, taxpayers, industry and others questioned the laws' effectiveness. In addition, easy technological solutions and specific standards did not adequately address the complicated nature of environmental protection. The complicated interconnections of the third generation forced federal regulatory agencies to turn to more and more complicated methods to identify pollution and its effects. This "it's complicated" generation allowed for many interpretations and solutions for pollution's consequences [14]. This generation at times did have skeptics that questioned the consequences of environmental pollution (e.g., ozone hole and chlorofluorocarbons) but few government decision makers listened to the skeptics and denied the pollution and its effects [20].

The election of Donald Trump and the rise of Congressional decision makers who are climate change skeptics and deniers may have ushered in the beginnings of a fourth generation. This evolution takes the challenging and difficult questions asked during the third generation and concludes that the problems do not exist, or they are not the consequences of human activity [21]. For example, the Trump Administration and Congressional representatives have called climate change a hoax [21,22]. The evolution connects back to the Reagan Administration's desire to reduce the size and scope of federal governmental activities and bring a free market approach to corporate activities. But unlike the Reagan and first Bush Administrations, the proponents and leaders are actively ignoring human health, infrastructure and environmental damages from the pollutants (e.g., proposed elimination of the Clean Power Plan and statements that global climate change is a hoax). Governmental decision makers are taking the small government ideals of the Reagan Administration and connecting them to the alt-right conspiracies that global warming and other environmental problems are not happening, not caused by humans, or a big government conspiracy [23].

\section{The Creation of the National Environmental Policy Act}

Jackson and other Congressional representatives developed NEPA during the first generation but its look to the future and its complex development allowed it to transcend the first generation. Throughout the three generations and perhaps fourth generation of environmental protection policy, NEPA has continued to function with few changes to its core mission. The law has allowed environmental reviews to occur prior to major infrastructure spending and has been used to make substantial changes to governmental projects. The reasons for its successes revolve around the motivations for its passage. Nixon, Jackson, the media, the American public, and Congressional decision makers saw the limitations of existing environmental policy as the media splashed photos of oil-covered birds and beaches, and observed the ineffectual decision making by Interior Secretary Walter Hickel and the inability of the oil companies to contain and stop the spill. They knew something needed to be done. In addition, Senators Jackson and Edmund Muskie (D-Maine) showed the decisions made before the spill allowed for lax regulatory review, approval, and oversight [8]. 
After the spill Jackson used Congressional hearings to provide evidence that the Interior Department and other executive agencies did not consider the environmental effects of federal projects. In addition, the lack of planning caused extensive environmental damage. The spill became the catalyst for Jackson's bill. He had been working on creating federal environmental policy since early 1966 with the hiring of William J. Van Ness, Jr. as a Special Counsel to Jackson's Senate Interior Committee. Jackson had been frustrated over the inability of federal agencies and offices to coordinate with each other on large projects. Van Ness began to read about planning when he and came across the writings of Lynton Caldwell. Van Ness was intrigued by a paper presented at a Conservation Foundation forum in 1965 entitled, "Administrative Possibilities for Environmental Control." In the paper, Caldwell specifically critiques the "unplanned, uncoordinated, and often cross-purpose pursuits of individuals, corporations, and governmental agencies, all seeking their own objections and seldom with regard for the cumulative consequences" on the environment [24] (p. 651) $[25,26]$. The statement spoke to the frustrations of Jackson. Caldwell built on the ideas from his earlier paper by specifically describing three prerequisites for government to develop a system for comprehensive and effective environmental policy. Firstly, he stated that vision and leadership must be a "slow and random accumulation of concepts and ideas" with many people integrating these ideas along with the desire to resolve conflicts and solve problems. Secondly, decision makers along with public action were essential to create a "minimal consensus" to understand the need for action. In 1966, he described an American public that was indifferent and did not see the environmental decline occurring throughout the United States. He believed a small group of committed people could get together and work to create comprehensive change-environmental policy was no different. To explain minimal consensus, he described the actions of the small group that worked to create the Wilderness Act in 1964 [27]. Finally, he stressed that the federal government needed an instrument to bring comprehensive environmental policy to fruition [24] (pp. 651-653). Van Ness had his blueprint to reduce Jackson's frustrations with planning.

As Van Ness worked to convince Jackson that Caldwell's ideas would allow the federal government to develop projects that required myriad agencies to work together on infrastructure projects and minimized environmental harm, the Interior Department was creating the situation that would give Jackson the impetus to finally convince his colleagues to vote for his legislation. In 1966, the Johnson Administration and its budget agency pushed the Interior Department to fast track the sale of oil leases in the Santa Barbara Channel. But Johnson's Interior Department ran into the protests of Santa Barbara residents and government officials. Residents and officials feared that the increased number of platforms in the channel along with no state or local oversight would cause increased pollution and blight. While the tideland suits between federal and state ownership halted the installation of offshore oil platforms until the late 1960s, Santa Barbara residents slowly permitted the installation of eight platforms on state tidelands. Each of the installation involved coordination with local residents. The Interior Department approved the first federal drainage lease sale in January 1967 A drainage lease sale allows for a quick approval due to an adjacent producing lease. One month before in December 1966, a Federal Register notice requested recommendations for leasing of federal tidelands for oil and gas exploration and production. The Interior Department officials flippantly considered the concerns of the Santa Barbara residents when they remarked that there was public concern about adverse effects on the "natural beauty" of the area $[8,28]$.

From a federal standpoint, there were no regulations to include state or local representatives and citizens in the leasing process. Public hearings were not required. Regardless of the lack of any requirements, Moore hoped to easily persuade the Santa Barbara officials of the benefits of the federal platforms. He had underestimated the opposition. At the first meeting in Washington D.C., the Santa Barbara officials requested a formal moratorium on any further federal lease sales. When this was swiftly rejected by Interior officials, they asked for a limited number of sales and a buffer zone around the existing state sanctuary. With no easy compromise in sight, Moore agreed to visit Santa Barbara. During the eleven weeks between the two meetings, the Interior Department continued to plan for the lease sale. The Bureau of Budget hoped to raise \$375 million for fiscal year 1968 [29]. At the same time, 
Santa Barbara officials found hope with the promise of a second meeting. Officials in Santa Barbara cities banned the siting of onshore oil processing facilities and passed resolutions to stop all federal offshore leases. To prepare for the Santa Barbara meeting, the officials planned to formally request an expansion of the existing state sanctuary and a one year moratorium on lease sales until more robust regulations could be created to protect the channel and its ecosystem. At the Santa Barbara meetings, every request for state or local review or additional time Moore brushed aside with the reply that the Interior Department's "basic responsibility" was to exploit natural resources for increased revenues [8] (p. 37). In other words, protection of the environment was a secondary concern for Johnson's Interior Department during the negotiations for offshore oil and gas development. Remember, the Interior Department also has primary responsibility for preserving federal lands under laws as varied as the Wilderness Act of 1964 and the National Park Service Organic Act of 1916. In addition, the Johnson Administration was integral in the passage of the Highway Beautification Act of 1965. Moore and Standley did not consider environmental protection or conservation as part of their mission. During the hearings following the spill, this exploitation strategy of Johnson's Interior Department became the raison d'etre for the passage of NEPA. The contradictory policy goals provided Jackson with evidence for a more comprehensive policy since even a single agency like the Interior Department did not prioritize environmental concerns when developing natural resources for revenues.

In the meeting, Interior officials pushed aside concerns over pollution. Moore stated that any leaks would be contained at the boreholes or developed well casings. No oil seepage could happen [30]. Again, the statements conflicted with the activities of other Interior Department agencies. During the negotiations, Interior officials were working with English and French officials to assist in a large oil spill off the Cornish coast from the grounding of the Torrey Canyon-an oil tanker. The spilled oil and the failed attempts to remove and contain it caused considerable damage to the marine ecosystem. For example, studies determined that the chemicals used to disperse the oil were more toxic than the spilled crude oil. As oil companies and international environmental officials helplessly attempted to contain the spill of thirty-five million gallons of crude oil that covered the Cornish and Brittany coasts, Johnson requested his cabinet officials to create a coordinated approach to major environmental incidents. The National Contingency Plan created written plans for federal responses to oil spills and hazardous substance releases. The bifurcated responses showed that inside federal agencies offices were unable to see the connections between actions that involved oil pollution and its effects.

In addition, the oil companies were pressuring the Interior Department to open the entire channel to oil exploration and production. Moore and Johnson's Interior Secretary Stewart Udall had friendly relationships with oil industry representatives and they met with them on a regular basis. The oil companies had invested millions of research dollars into deep water platforms and they hoped to use the technology in the Santa Barbara channel. Moore understood the concerns of the oil companies, but he lobbied for a buffer zone around the state sanctuary to placate the residents and officials. He also knew that the buffer zone would not affect the revenues of the oil companies and the federal government. He hoped they would eventually agree to the compromise. The Santa Barbara officials did not. Secretary Udall, the author of The Quiet Crisis gave the Santa Barbara officials an additional sixty days to comment on the new lease sale documents [31,32]. Interior Department understood that the sixty-day review was window dressing and the Bureau of Budget complained that there was no mechanism to stop the lease sale so why wait an additional sixty days. The lease sales would occur as soon as they could after the sixty-day period. In a final desperate act, Santa Barbara representatives requested a hearing with the Corps of Engineers to comment on the location of an existing platform. The Corps of Engineers was the only agency with a requirement to hold hearings if requested; the Interior Department had no such requirement. In addition, the Corps of Engineers only has jurisdiction over navigation; therefore, questions regarding the spills, aesthetics and other issues were ignored. In a memo, Standley warned the Corps that they had no jurisdiction and they "preferred to not stir the natives up any more than possible [33]". At the hearing after the spill, this statement showed the contempt some Interior officials had for the people of Santa Barbara. 
The oil companies wanted to re-coop their costs and the Johnson Administration wanted the revenues. Nothing would stop the problems.

Standley's statement and the lack of a forum for citizens and others to bring their environmental and health concerns to federal agencies revealed that the federal government did not have a mechanism for considering infrastructure's effect on the environment. At hearings immediately after the spill, Senator Alan Cranston (D-California) used Standley's quote to describe the lack of engagement and interest of the Interior Department officials to the concerns of the local officials [11] (p. 1291). At the same hearing, Alvin Weingand, chair of the Santa Barbara group, Get Oil Out! (GOO!) described Udall's November 1967 visit-where Udall attempted one last time to persuade Santa Barbara residents and officials that drilling and ecosystem protection were not mutually exclusive [11] (p. 624). Udall gave his speech at the University of California, Santa Barbara's convocation ceremony-not at a public hearing [32,34]. The speech revealed that the Interior Department had already decided to hold the lease sales. Before the end of 1967, Udall approved the lease sale of 845 square miles of federal tidelands in the Santa Barbara channel $[35,36]$. One year later the assurances of Udall proved to be meaningless.

As the Interior Department worked to open up the channel for revenues regardless of environmental impact, Senate Interior Affairs Committee Chair Jackson began to be convinced that the federal government needed to create a more comprehensive environmental policy. Special Counsel Van Ness knew that creating a law that required the desperate agencies to work together would take years of agenda setting and policy development. Negotiations started slowly. He first needed to persuade Jackson to follow Caldwell's recommendations. Van Ness explained to Jackson that considering the environment as a policy focus instead of concentrating on single issues such as airport construction, timber producing, or flood control would be more effective for reducing pollution and managing federal land and dollars. Jackson immediately understood the new paradigm. In January 1967, at the same moment that Udall approved the channel lease sales, Jackson included a Van Ness memo into the Congressional Record. Van Ness argued that the federal government did not have the ability or mandate to assess its action and the resulting effects on the environment. Therefore, the environment needed an organizing policy for the federal government $[25,26,37]$.

Jackson slowly made the case for comprehensive environmental policy. In his next step, he introduced a bill into Senate Interior Committee for hearings. But he knew few Congressional representatives considered conservation and environmental protection to be important issues [38]. In addition, cabinet secretaries would also object to congressional measures that interfered with their core missions. Secretary Udall was one of the secretaries. During the hearings and conversations, Jackson and Van Ness were unaware of the Santa Barbara lease sales and the objections of the local residents and Udall's role in the sales.

Jackson understood that NEPA was a bill that forced inter- and cross disciplinary thinking and actions. NEPA would allow the federal government to consider the risks and benefits of their actions. Jackson wanted agencies to consider the effects to water, air and land and determine if there were better methods to spend federal tax dollars. Using the Caldwell's blueprint, he developed a mission statement for environmental policy. Unlike many of the laws passed before 1980, the six provisions of NEPA are proactive statements that look to the future. NEPA states the federal government will:

(1) fulfill the responsibilities of each generation as trustee of the environment for succeeding generations; (2) assure for all Americans safe, healthful, productive, and esthetically and culturally pleasing surroundings; (3) attain the widest range of beneficial uses of the environment without degradation, risk to health or safety, or other undesirable and unintended consequences; (4) preserve important historic, cultural, and natural aspects of our national heritage, and maintain, wherever possible, an environment which supports diversity and variety of individual choice; (5) achieve a balance between population and resource use which will permit high standards of living and a wide sharing of life's amenities' and (6) enhance the quality of renewable resources and approach the maximum attainable recycling of depletable resources [37] (pp. 2-3). 
NEPA's goals can be considered an early attempt at creating a sustainability and resilience program. They encompass the first three generations of environmental regulatory development. The first statement asks the agencies to consider future generations in decision making. Very little of the command and control language of first generation laws is present. In addition, the second generation's analysis of costs and benefits filters through the statements. The third provision specifically mentions risks and benefits. In addition, the fifth condition directs the federal government to analyze the tradeoffs to allow for resource use and a high standard of living. Ultimately, it also shows that the process of environmental impact thinking will be holistic and complicated with few easy answers. The language of the mission statement developed by the principal architects of NEPA resulted from the events in 1968 and 1969 in Santa Barbara.

Jackson and Van Ness worked slowly and deliberately to convince senators, representatives and eventually Nixon that human actions had the potential to alter their physical surroundings. Therefore, the federal government needed to take the lead to consider the effects government projects had on air, water, land and myriad issues relating to health and safety, natural heritage and natural resource extraction. Of course, Jackson recognized he needed to work within the confines of Congressional sessions. Therefore, in the 1968, he collaborated with his House colleagues to develop a bill for passage. Since Jackson had started his career in the House, he was aware of the differences between the two bodies. In the 1960s, House committee chairs tended to rule their committees with strict hierarchies. Jackson did not want to wait the eight years it took to finalize the Wilderness Act; therefore, he worked with John Dingell (D-Michigan) to ensure that the bill did not get introduced in Wayne Aspinall's House Interior and Insular Affairs Committee. Aspinall (D-Colorado) took his time with pending legislation and Jackson knew Aspinall would not prioritize the bill. Dingell requested the bill be assigned to the Committee on Science and Aeronautics chaired by George Miller (D-California) [31]. The committee appears to be a strange place for an environmental bill but Dingell remembered that the committee published a reported in 1966 titled, "Environmental Pollution: Challenge to Science and Technology" [39]. Ultimately after the 1968 election, Dingell introduced the bill in the Committee on Merchant Marines and Fisheries. The committee switch made sense since the House committee had jurisdiction over the open ocean and held hearings that dealt with the oil pollution from the Santa Barbara spill. In addition, twenty-one of the thirty-two committee members lived in coastal states. Dingell recognized that the committee members saw the connections between comprehensive environmental policy and the Santa Barbara spill.

Outside of Congressional constraints, Jackson and Van Ness met directly with Caldwell to develop a more detailed blueprint for the bill. With this step, Jackson finally introduced a first draft of the bill to the Senate Interior Committee. Caldwell with funding from the Conservation Foundation crafted the report, "A National Policy for the Environment" to provide additional information on a national policy to cope with the "environmental crisis [40]." The slow process allowed Jackson and Van Ness to thoughtfully and deliberately create a bill that transformed the way the federal government developed infrastructure projects. As part of the process, Jackson identified the need for Council on Environmental Quality that would counsel the president in the same way as the Council on Economic Advisors [25] (p. 316). In addition to the statement of policy and the Council on Environmental Quality, the final bill described that the public and state and local governmental officials have the right to review and comment on the environmental impact statements [40] (pp. 2-4). No longer could federal officials ignore public comments to federal projects NEPA does give the president some leeway for removing projects from the EIS process (e.g., national security).

Jackson hoped to introduce the bill to the full Senate before the 1968 election but the lack of support from the Johnson Administration and the lack of urgency from his Senate and House colleagues continued to plague any movement. Few groups believed that an environmental policy was needed. So, Jackson stepped back and waited until after the next election. The election of Nixon did not provide Jackson with optimism that the law would pass in the next session of Congress. He planned 
to re-introduce a new bill in the first few months of the next session and continue the slow battle for passage. The Santa Barbara spill changed his strategy.

With the spill and its effects spread across television stations and hearings in Muskie's Subcommittee on Air and Water Pollution and additional hearings in the House, Jackson saw the spill as an opportunity to press for quick passage. The oil spill hearings provided the justification for a comprehensive environmental policy. The testimony from former Interior Secretary Udall proved powerful. Prior to the spill, he had testified at a House-Senate colloquium that an environmental policy was not needed [41] (pp. 12-17). But his actions in Santa Barbara before the lease sale showed that he downplayed environmental concerns. Prior to the creation of the U.S. EPA, the Interior Department had jurisdiction over some aspects of water pollution. At a hearing, Udall acknowledged that his Interior Department had not taken the lead on water pollution. He testified that "at the time we made the Santa Barbara decision there was no dissent in the Department. This was sort of a conservation 'Bay of Pigs,' you might say ... but there was nobody hammering on the door and there is nothing in the record ... that would indicate someone was saying 'This is a mistake,' and predicting that what occurred would occur [8] (pp. 159-160) [11] (p. 1208)." Of course, Udall's memory was faulty. At one meeting, at least three local officials brought up the potential for water pollution. Jackson seeing an opportunity leapt and introduced S. 1075 on 18 February 1969-less than one month after the spill. S. 1075 did not yet include the statement of environmental policy.

Caldwell took the lead on promoting a substantial environmental policy statement. He stated that the statement should be "operational". Jackson responded with a statement that goes to the heart of NEPA and its success. "I am wondering if we might not broaden the policy provision in the bill so as to lay down a general requirement that would be applicable to all agencies that have responsibilities that affect the environment rather than trying to go through agency by agency [12] (pp. 116-117)". With the Santa Barbara spill as a backdrop, Jackson's Senate colleagues and the Nixon Administration jumped on board. They understood that the American public's interest in environmental quality had increased exponentially. In addition, Nixon, who was concerned that either Jackson or Muskie would run against him needed to prove his leadership in environmental concerns after the fumbled response to the spill. Nixon chose to get behind Jackson's bill since he expected Muskie to provide a stronger challenge in the next election. Jackson, Van Ness and Caldwell drafted a version of the environmental policy statement. To strengthen the amendment, Jackson had Senate Majority Leader Michael Mansfield (D-Montana) to introduce it. Fewer than six months after the spill, the Senate passed NEPA with a unanimous voice vote. The House passed the bill in September with a vote of 372 to 15 . Nixon signed the bill with a strong statement of support. He stated, "By my participation in these efforts I have become further convinced that the 1970s absolutely must be the years when America pays its debt to the past by reclaiming the purity of its air, its waters, and our living environment. It is literally now or never [4]".

\section{Conclusions}

NEPA would prove to be a success for informed and sustainable decision making at the federal level. Openness and transparency are two of the bedrocks of the law. Citizens and others have a place at the table and they have a process for their concerns. Federal agencies can no longer ignore them like they did the residents of Santa Barbara. The NEPA process allows for public comments and requires federal agencies to consider environmental effects. The Environmental Impact Statement (EIS) is the cornerstone of the law. It requires the government to explain its decision-making process and consider the concerns and ideas of the American people. Its critics have complained that NEPA has slowed the process for development but at the same time it has allowed more voices into the process so that the final decisions are more sustainable [42]. From its inception, NEPA acknowledged that considering environmental effects is a complicated process but ultimately a rewarding process [43]. It foresaw the issues that became apparent during the Clinton and George W. Bush Administrations. There were no easy fixes. The decisions needed to consider the costs, benefits and environmental and human health 
impacts of federal projects. Caldwell, Van Ness, and Jackson's insights allowed the law to permeate federal decision making. NEPA and its associated EISs and Environmental Assessments (EA) have saved wetlands from development, protected campers and endangered species from aircraft noise, removed uranium tailings from the Colorado River, stopped the paving over a historic brick road and the list goes on and on [44].

NEPA has transcended the three generations of environmental regulatory development. It has embraced the complications and risk analysis while allowing the voices of all parties to take part in the process. The public, industry, non-governmental organizations, federal, state and local government agencies participate on an almost equal footing during the planning process. Including these voices created a more sustainable and resilient process for infrastructure projects. As the Trump Administration proposes changes to the NEPA review process and we enter this proposed fourth generation, NEPA's democratic and open process will be needed to apply sustainable and resilient principles to federal projects that major Every project happens in someone's backyard and they deserve the protections of NEPA's processes. As the Trump Administration attempts to build a border wall from California to Texas and open the Arctic National Wildlife Refuge and the OCS with little to no environmental review, issues of national security and energy independence need to be considered as part of the NEPA process The Trump Administration has proposed that the construction of a 15-mile section of the border wall near San Diego does not require review under NEPA since it is exempt under Section 102 of the Illegal Immigration Reform and Immigrant Responsibility Act of 1996 (IIRIRA). There is concern that he may use the IIRIRA exemption to bypass environmental review of his proposed border wall. NEPA has created a sustainable and resilient process for federal government transparency. The people and marine organisms of Santa Barbara paid the price for the lack of transparency and public participation and Congressional representatives and a Republican president learned from the mistake. Twenty-first century policy makers need to consider NEPA's history before they overturn its core mission.

Funding: This research received funding from the Rachel Carson Center for Environment and Society at the Ludwig-Maximilians-Universität München; University of Houston, Energy Management and Policy Group and Department of History; NSF-DGE\#0114432, the UC Davis Biological Invasions IGERT; Summer Research Grant, Historical Society of Southern California; and Reed Travel Grant, University of California Davis, History Department.

Acknowledgments: The author would like to thank Tanja Srebotnjak and the Hixon Center for Sustainable Environmental Design for their encouragement to return to the Santa Barbara spill for additional inspiration. Also I want to thank the students in my Spring 2018 EA93 Domestic Environmental Policy course at Pitzer College for analytical support.

Conflicts of Interest: The author declares no conflict of interest.

\section{References and Notes}

1. Hays, S.P. Beauty, Health and Permanence: Environmental Politics in the United States, 1955-1985; Cambridge University Press: Cambridge, MA, USA, 1987.

2. Rome, A. The Bulldozer in the Countryside: Suburban Sprawl and the Rise of American Environmentalism; Cambridge University Press: Cambridge, MA, USA, 2001.

3. Whitaker, J.C. Striking a Balance: Environment and Natural Resources Policy in the Nixon-Ford Years; American Enterprise Institute: Washington, DC, USA, 1976.

4. Nixon, R.M. Statement about the National Environmental Policy Act of 1969. 1 January 1970. Available online: http:/ / www.presidency.ucsb.edu/ws / ?pid=2557 (accessed on 27 July 2018).

5. Caldwell, L.K. Environment: A New Focus for Public Policy? Public Admin. Rev. 1963, 23, 132-139. [CrossRef]

6. United States v. California, 381 U.S. 139. 1964.

7. United States v. California, 382 U.S. 448. 1965.

8. Spezio, T.S. Slick Policy: Environmental and Science Policy in the Aftermath of the Santa Barbara Oil Spill; University of Pittsburgh Press: Pittsburgh, PA, USA, 2018.

9. Deep Water: The Gulf Oil Disaster and the Future of Offshore Drilling; National Commission on the BP Deepwater Horizon Oil Spill and Offshore Drilling: Washington, DC, USA, January 2011. 
10. Hearings before the Senate Subcommittee on Air and Water Pollution of the Committee on Public Works on S. 7 and S. 544 on Water Pollution-1969 (Part 3). In Proceedings of the U.S. Senate 91st Congress, Washington, DC, USA, 24-25 February 1969.

11. Hearings before the Senate Subcommittee on Air and Water Pollution of the Committee on Public Works on S. 7 and S. 544 on Water Pollution-1969 (Part 4).

12. Hearing before the Committee on Interior and Insular Affairs on S. 1075, S. 238 S. 1752-National Environmental Policy. In Proceedings of the U.S. Senate 91st Congress, 1st Session, Washington, DC, USA, 16 April 1969.

13. Bartley, E.R. The Tidelands Oil Controversy: A Legal and Historical Analysis; University of Texas Press: Austin, TX, USA, 1953.

14. Fiorino, D.J. The New Environmental Regulation; MIT Press: Cambridge, MA, USA, 2006.

15. Mazmanian, D.A.; Kraft, M.E. Toward Sustainable Communities: Transition and Transformations in Environmental Policy, 2nd ed.; MIT Press: Cambridge, MA, USA, 2009.

16. U.S. Environmental Protection Agency Office of Air and Radiation. The Benefits and Costs of the Clean Air Act, 1970 to 1990; GPO: Washington, DC, USA, 1997.

17. U.S. Environmental Protection Agency Office of Air and Radiation. The Benefits and Costs of the Clean Air Act, 1990 to 2010: EPA Report to Congress; GPO: Washington, DC, USA, 1999.

18. U.S. Environmental Protection Agency Office of Air, and Radiation. The Benefits and Costs of the Clean Air Act, 1990 to 2010: Final Report-Revision A; GPO: Washington, DC, USA, 2011.

19. Krupnick, A.; Morgenstern, R. The Future of Benefit-Cost Analyses of the Clean Air Act. Annu. Rev. Public Health 2002, 23, 427-428. [CrossRef] [PubMed]

20. Taubes, G. The Ozone Backlash. Science 1993, 260, 1580-1583. [CrossRef] [PubMed]

21. Benson, M.H.; Craig, R.K. Welcome to the Anthropocene. In The End of Sustainability: Resilience and the Future of Environmental Governance in the Anthropocene; Benson, M.H., Craig, R.K., Eds.; University Press of Kansas: Lawrence, KS, USA, 2017; pp. 1-21.

22. Inhofe, J.M. The Greatest Hoax: How the Global Warming Conspiracy Threatens Your Future; WND Books: Washington, DC, USA, 2012.

23. McComiskey, B. (Ed.) Post-Truth Rhetoric and Composition. In Post-Truth Rhetoric and Composition; University Press of Colorado: Boulder, CO, USA, 2017; pp. 1-50.

24. Caldwell, L.K. Administrative Possibilities for Environmental Control. In Future Environments of North American; Darling, F.F., Milton, J.P., Eds.; The Natural History Press: Garden City, KS, USA, 1966; pp. 648-671.

25. Finn, T.T. Conflict and Compromise: Congress Makes a Law, the Passage of the National Environmental Policy Act. Ph.D. Thesis, Georgetown University, Washington, DC, USA, December 1972.

26. Wertz, W.R. Lynton Keith Caldwell: An Environmental Visionary and the National Environmental Policy Act; Indiana University Press: Bloomington, IN, USA, 2014.

27. Harvey, M. Wilderness Forever: Howard Zahniser and the Path to the Wilderness Act; University of Washington Press: Seattle, WA, USA, 2007.

28. Crow, J. Memorandum to Thomas Nolan, Secretary of the Interior, Call for nominations for Oil and Gas Leasing Offshore California; Muskie Archives: Lewiston, ME, USA, 15 December 1966.

29. Shultz, C.L. Memo to Stewart Udall on Actions to Stimulate Revenues from the Federal Outer Continental Shelf Oil Leasing Program; Udall Archives: Denver, CO, USA, 20 November 1967.

30. Standley, E. Memo to File-Meeting on O.C.S. Leasing in the Santa Barbara Channel, California; Muskie Archives: Lewiston, ME, USA, 10 April 1967.

31. Udall, S.L. The Quiet Crisis; Holt, Rinehart and Winston: New York, NY, USA, 1963.

32. Privacy, Tranquility in Jeopardy —Udall; Santa Barbara News-Press: Santa Barbara, CA, USA, 17 November 1967.

33. Standley, E. Minutes of Meeting with Jordan in the Pentagon; Muskie Archives: Lewiston, ME, USA, 15 February 1968.

34. Buffum, R. Controlled Oil Development by Feds Offshore Inevitable; Goleta Gazette Citizen: Santa Barbara, CA, USA, 23 November 1967.

35. Anderson, H.R. Memo to Secretary of the Interior (Udall)_OCS Oil and Gas Lease Sale_Santa Barbara Channel Area; Muskie Archives: Lewiston, ME, USA, 18 December 1967.

36. Crow, J. Notice of Oil and Gas Lease Sale-Outer Continental Shelf off California; Muskie Archives: Lewiston, ME, USA, 20 December 1967. 
37. House Conference Report-National Environmental Policy Act of 1969. In Proceedings of the U.S. House of Representatives 91st Congress, 1st Session, 17 December 1969.

38. Frome, M. Rate Your Candidate; Field \& Stream: Coraopolis, PA, USA, September 1968.

39. Environmental Pollution, Challenge to Science and Technology. In Proceedings of the U.S. House of Representatives. Science, and House Astronautics Committee 89th Congress, 2nd Session, Washington, DC, USA, 1966.

40. Caldwell, L.K. A National Policy for the Environment: A Special Report to the Committee on Interior and Insular Affairs. In Proceedings of the United States Senate 90th Congress, Washington, DC, USA, 11 July 1968.

41. Hearing before the Committee on Interior and Insular Affairs and Committee on Science and Astronautics-Joint House-Senate Colloquium to Discuss National Policy for the Environment. In Proceedings of the U.S. Senate 90th Congress, 2nd Session, Washington, DC, USA, 17 July 1968.

42. Kysar, D.A.; McGarity, T.O. Did NEPA Drown New Orleans? The Levees, the Blame Game, and the Hazards of Hindsight. Duke Law J. 2006, 56, 179-235.

43. Murphy, A.W. The National Environmental Policy Act and the Licensing Process: Environmentalist Magna Carta or Agency Coup De Grace? Columbia Law Rev. 1972, 72, 963-1007. [CrossRef]

44. Environmental Law Institute. NEPA Success Stories: Celebrating 40 Years of Transparency and Open Government; Environmental Law Institute: Washington DC, USA, 2010.

(C) 2018 by the author. Licensee MDPI, Basel, Switzerland. This article is an open access article distributed under the terms and conditions of the Creative Commons Attribution (CC BY) license (http://creativecommons.org/licenses/by/4.0/). 